\title{
VIRUS ELIMINATION IN POTATO THROUGH MERISTEM CULTURE FOLLOWED BY THERMOTHERAPY
}

\author{
M. A. Ali, K. M. Nasiruddin, M. S. Haque and S. M. Faisal ${ }^{* 1}$ \\ Department of Biotechnology, Faculty of Agriculture, Bangladesh Agricultural University, \\ Mymensingh-2202
}

\begin{abstract}
Virus elimination in potato through meristem culture followed by thermotherapy and virus indexing was studied. Three levels of thermotherapy, viz. $27 \pm 1^{\circ} \mathrm{C}$ (control), $30 \pm 1^{\circ} \mathrm{C}$ and $35 \pm 1^{\circ} \mathrm{C}$, sixteen combinations of BAP (Benzyl Amino Purine) plus $\mathrm{GA}_{3}$ (gibberellic Acid) concentrations viz. 0.0+0.0 (control), 0.0+0.2, 0.0+0.4, 0.0+0.6, 1.5+0.0, $1.5+0.2,1.5+0.4,1.5+0.6,3.0+0.0,3.0+0.2,3.0+0.4,3.0+0.6,4.5+0.0$, $4.5+0.2,4.5+0.4$ and $4.5+0.6$ were used in this study in three potato varieties viz. Diamant, Heera and Lalpakri. Among the thermo therapies, $27 \pm 1^{\circ} \mathrm{C}$ showed the highest (24.55) survival response followed by $30 \pm 1^{\circ} \mathrm{C}, 35 \pm 1^{\circ} \mathrm{C}$, respectively. The poorest $(20.47)$ survival response of meristem derived plantlets was noticed in $35 \pm 1^{\circ} \mathrm{C}$ which gave the highest percentage (43.79) of virus free plantlets followed by $30 \pm 1^{\circ} \mathrm{C}$. The best $(25.85 \%)$ survival response was found in Lalpakri and the lowest (19.08\%) survivality was recorded in Diamant. The highest (33.27) percentage of PVY (Potato Virus $Y$ ) free plantlets was observed in Heera. The combined treatment $3.0 \mathrm{mg} \mathrm{L}^{-1}$ BAP and $0.2 \mathrm{mg} \mathrm{L}^{-1} \mathrm{GA}_{3}$ showed the highest (63.39) percentage of virus free plantlet production followed by $4.5 \mathrm{mg} \mathrm{L}^{-1} \mathrm{BAP}$ and $0.2 \mathrm{mg} \mathrm{L}^{-1} \mathrm{GA}_{3}$.
\end{abstract}

Key words: Potato, meristem, ELISA (Enzyme Linked Immuno-Sorbent Assay), BAP, $\mathrm{GA}_{3}$.

\section{INTRODUCTION}

Potato (Solanum tuberosum L.) is the 4th most cultivated food crop after wheat, rice and maize and therefore, the most important dicotyledonous and tuber crop in the world (Jones et al., 1994). Potato is a good and cheap source of carbohydrates, vitamins, minerals and proteins and provides most of the trace

\footnotetext{
* Corresponding author email: osru2002@yahoo.com

${ }^{1}$ Senior Scientific Officer, Horticulture Division, RARS, BARI, Hathazari, Chittagong, Bangladesh
} 
elements which can meet the energy requirements of the people living in the developing countries. It is cultivated over an area of 345 thousand hectares with an annual production of 5167 thousand tones with an average yield of $14.83 \mathrm{t} \mathrm{ha}^{-1}$ (BBS, 2007). This yield is very low compared to other countries like the Netherlands (45 t $\left.\mathrm{ha}^{-1}\right)$, Germany (46 t ha-1), Scandinavian countries (48-52 $\mathrm{t} \mathrm{ha}^{-1}$ ) and neighbouring India (21 t ha-1) (Beukema and Vander Zaag, 1990; Rashid et al., 1993). Lack of quality seed potato is one of the most important factors for this low yield.

Most of the farmers in Bangladesh use degenerated seeds obtained from cold storage owners, farmers and traders. At present Bangladesh imports only a few hundred tones of high quality seed potatoes of some modern varieties, mostly from the Netherlands, for further multiplication by BADC (Bangladesh Agricultural Development Corporation) and private seed potato producers. On the other hand, the local varieties of potato which are tolerant to diseases and environmental stresses cover nearly $36 \%$ of the total potatoes cultivated in the country (Siddique and Hussain, 1988). In tropical and subtropical areas like Bangladesh, it is difficult to produce seed tubers of potato due to lack of appropriate storage facilities and transport, as well as the presence of active virus diseases vectors (Omidi et al., 2003). Plant tissue culture offers an efficient method for production and rapid propagation of pathogen-free material and germplasm preservation of plants to overcome this unwanted situation. Diseased free good quality seeds and pathogen free planting materials are produced through tissue culture.

Thermotherapy is an important pre-requisite for meristem culture. Thermotherapy reduced the incidence of PLRV (Potato Leaf Roll Virus) and PVS (Potato Virus S) by 45\% and 50\%, respectively (El-Amin et at., 1994). More virusfree plants were obtained when heat treatments were included (Zapata et al., 1995). Seed health is the prime consideration for potato production, which can be retained by lowering the number of field generations. The conventional method of clonal selection is time consuming and requires intensive control over large areas of land with low rates of multiplication (Van der Zaag, 1987). Rapid multiplication with a reduction to three generations of seed multiplication from 7 in conventional clonal selection gave a $25 \%$ increased yield and better seed quality in Ecuador (Bryan, 1989). Based on the above facts, the present work was undertaken to fulfill the following objectives- 1) to see the effect of thermotherapy on virus elimination in meristem cultured seed potato and 2) to establish a suitable and reproducible in vitro regeneration protocol of potato varieties for quality seed potato production.

\section{MATERIALS AND METHODS}

The investigation was conducted at the USDA sponsored (United States Department of Agriculture) Biotechnology Laboatory at Bangladesh Agricultural University, Mymensingh during January 2005 to December 2008, as a part of Ph.D. research works. There were three factors in this experiment. Factor A consisted of 
three levels of thermotherapy, viz. $27 \pm 1^{\circ} \mathrm{C}$ (control), $30 \pm 1^{\circ} \mathrm{C}$ and $35 \pm 1^{\circ} \mathrm{C}$, Factor B consisted of three potato varieties viz. Diamant, Heera and Lalpakri and Factor $\mathrm{C}$ consisted of sixteen combinations of cytokinin (BAP) plus gibberellin $\left(\mathrm{GA}_{3}\right)$ concentrations viz. $0.0+0.0$ (control), $0.0+0.2,0.0+0.4,0.0+0.6,1.5+0.0,1.5+0.2$, $1.5+0.4,1.5+0.6,3.0+0.0,3.0+0.2,3.0+0.4,3.0+0.6,4.5+0.0,4.5+0.2,4.5+0.4$ and 4.5+0.6. So, total number of treatments were $144(3 \times 3 \times 16)$. Four explants were placed in a test tube and replicated 3 times. The experiment was done in Completely Randomized Design (CRD). In this study MS (Murashige and Skoog, 1962) medium was used as basal medium.

Two sets, each containing plant materials of three potato varieties infected by PVY were selected. Each set consisted of 18 plants- affected by PVY, field symptoms and serological confirmation followed by ELISA test. After maturity the PVY infected potato tubers of three varieties were collected and stored carefully. PVY infected potato tubers of three varieties were kept under dark with 1 minute deeping in $1 \mathrm{ppm}$ concentration of $\mathrm{GA}_{3}$ for sprouting. For meristem collection 0.2 $0.5 \mathrm{~mm}$ long size meritems were selected. After dissection the excised meristems were cultured in MS medium supplemented with the sixteen hormonal combinations. Calli derived from excised meristems were treated with three temperature regimes.

All inoculations and manipulations were carried out aseptically unde laminar airflow cabinet. The physical conditions for growth and development of cultures were maintained at the temperature of $25 \pm 1^{0} \mathrm{C}$ and a light intensity of 2000-3000 lux provided by fluorescent tube. The photoperiod was maintained at 16 hours light and 8 hours dark (16L/8D) and the relative humidity was 60-70\%.

\section{Meristem Explants}

Meristem part was taken from leaf buds as top shoot meristems are covered by numerous soft bristles and thus difficult to isolate. Under a 50× magnification with stereoscopic microscope, the pedicel, immature leaves and the outer leaf primordia surrounding the meristem region were discarded one after another, using sharp microsurgical blades and pointed fine needle, until only the meristem region and one or two leaf primordia about $0.2-0.5 \mathrm{~mm}$ remain. At this stage, the manipulation was very delicate and care was taken not to damage the meristem region. When the age of the meristem derived plantlets were 65 days, they were sub cultured and placed under heat treatment.

\section{Multiplication by nodal cutting}

After 60-65 DAI (Days after inoculation) in vitro grown plantlets derived from meristems when attained a height of 4-6 cm were used for multiplication by nodal cutting. Each node of a plantlet consisted of 0.2-0.5 cm stem segment with an axillary bud and its subtended little leaf was cut aseptically and cultured in MS media. The cultures were incubated at the same conditions as was given for culturing meristems. 
M. A. Ali et al.

\section{Source of ELISA kits}

Antiserum, antibody conjugated with alkaline phosphatase (IgG conjugate) and positive control for PLRV, PVY and PVX (Potato Virus X) were collected through the courtesy of Deutsche Sammlung von Mikroorganismen und Zellkulturen GmbH (DSMZ), C/o. Biologische Bundesanstatt Institut fur Pflanzenvirologie, Mikrobiologie und Biologische Sicherheit, Messeweg 11/12, D-38104 Braunschweig, Germany.

\section{Virus indexing}

Near about 30-60 plantlets were developed from a single source by multiplication of nodal cuttings. Five plantlets of 40 days old from each set and each variety was tested by ELISA. This test was carried out for PVY. The sap of the plantlets was mechanically extracted in two separate polyethylene bags using a few drops of sample buffer.

\section{ELISA test}

The following materials were used for carrying out the test- i) ELISA microtitre plate with plastic lid, Dynatech cooke microtitre co. and ii) ELISA kit for PLRV, PVX and PVY of Mannhcim, West Germany which contained the coating buffer, washing buffer, extraction buffer, conjugate buffer, substrate buffer and substrate \{p-nitrophenyl phosphate (NPP) tablets .

\section{Observations}

Reaction was observed and red yellow color developed after 30-120 minute visually and/or photometrically at $405 \mathrm{~nm}$. Yellow color indicates presence of virus (Figure 4) and colorless absence of virus. The microtiter plates were placed inside a microtiter plate reader and the presence of virus was compared with positive and negative control samples in microtiter plate. Percentage of virus elimination was determined. There will be an antibody of respective virus as +ve and -ve control. +ve and -ve both will give absorbance result. A sample was considered positive if the absorbance was at least three times greater than that of the healthy control plant (negative control). Data on survival of meristem derived plantlets (\%) and virus free plantlets derived from meristem explants (\%) were recorded after 25 days of culture and arithmetic mean was worked out. The data were analyzed using MSTAT-C statistical software. Differences among the means were compared using LSD values.

\section{RESULTS AND DISCUSSION}

\section{Effect of thermotherapy on virus elimination in potato through meristem culture}

The meristem explants from sprouts of PVY affected potato tubers were subjected to thermotherapy of temperature $27 \pm 1^{\mathrm{O}} \mathrm{C}$ (control), followed by $30 \pm 1^{\circ} \mathrm{C}$ and $35 \pm 1^{\circ} \mathrm{C}$, respectively. The heat treatment was done after excision of meristem. Three different temperatures showed significant difference for survival of meristem 
derived plantlets and production of virus free plantlets derived from meristem of potato (Figure 1). It was found that, three different temperature regimes viz. $27 \pm 1^{\mathrm{O}} \mathrm{C}$, $30 \pm 1^{\circ} \mathrm{C}$ and $35 \pm 1^{\circ} \mathrm{C}$ showed positive responses regarding both the parameters studied. Among the thermotherapies, $27 \pm 1^{\mathrm{O}} \mathrm{C}$ showed the highest (24.55) survival response followed by $30 \pm 1^{\circ} \mathrm{C} .35 \pm 1^{\circ} \mathrm{C}$ showed the poorest (20.47) survival response of meristem derived plantlets. $35 \pm 1^{\mathrm{O}} \mathrm{C}$ gave the highest percentage (43.79) of virus free plantlets followed by $30 \pm 1^{\circ} \mathrm{C}$. The treatment, $27 \pm 1^{\circ} \mathrm{C}$ showed the lowest percentage (15.17) of virus free plantlets (Figure 1).

So, it was revealed that more increase in temperature during thermotherapy decreases the survival rate of meristem derived plantlets. But thermotherapy was a most important treatment with others to eliminate PVY from seed potato tuber (Figure. 2).

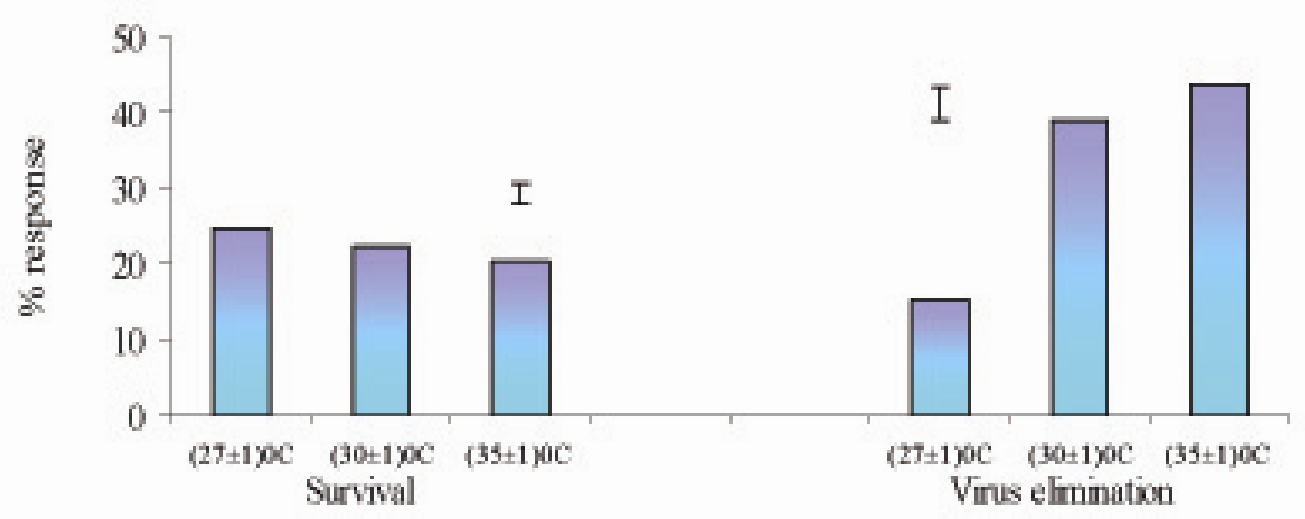

Figure 1. Effect of three levels thermotherapy on survival and virus elimaination of meristem derived potato plantlets.

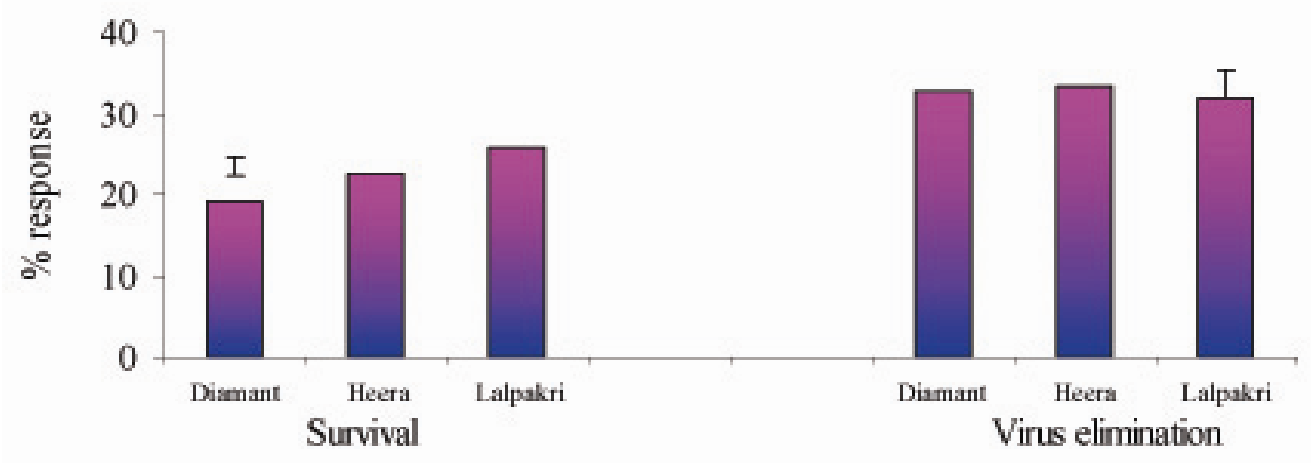

Figure 2. Responses of meristem derived potato plantlets of three potato varieties to three levels of thermotherapy for survival and virus elimaination. 
The most delicate part of plant is the meristematic zone, naturally which is very liable to injury or death by high temperature. That may be the reason of low survival rate of plantlets derived from meristems in thermotherapy treatment, where the meristems were given heat treatment after excision. Excised meristems was subjected to high temperature was not advocated suitable by many workers (Pennazio et al., 1978). Bjarnason (1986) observed a wide variation on the success of meristem when subjected to different temperature regimes both after and before excision of meristem. So, from this investigation it was revealed that, up to a critical level higher temperature treatment can eliminate more PVY viruses than the lower temperature treatment (Figure 3 and 4). Figure 5 showed the micro titer wells where no yellow colour was developed, that indicated the absence of PVY.

A wide variation was found in freeing PVY virus between temperature treated and non treated (control) plantlets which ranged from 43.79 to $15.17 \%$. Increased number of PVY virus free plantlets were obtained in the temperature treated meristem of potato than control. Similar findings were observed by Miller and Lipschutz (1984). Bokx (1972) stated that PVX is difficult to eliminate without temperature treatment. Pennazio et al. (1979) obtained very few or no virus free plants by meristem culture from infected plants without heat treatment. Size of meristem (Smith and Mellor, 1968) and size of explant (Zhuk, 1978) have critical role in virus elimination, so 0.3 to $0.7 \mathrm{~mm}$ long meristem with one or two leaf primordia produced high proportion of virus free plantlets. In the present investigation 0.2 to $0.5 \mathrm{~mm}$ size of meristem was used. From present study it may be concluded that presence of viruses in potato plants depends on heat therapy, nature of viruses, potato varieties and size of meristem.
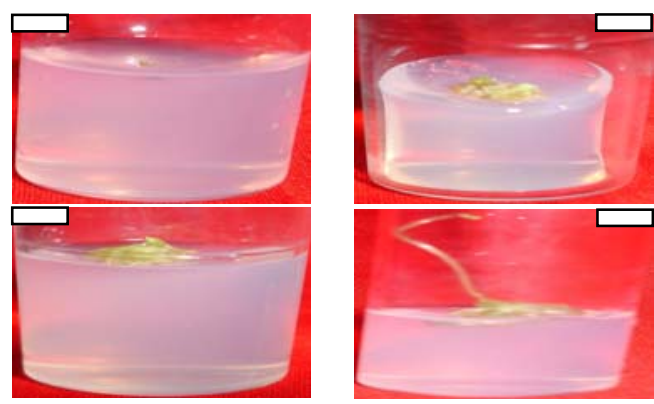

Figure 3. Successive stages of meristem culture in MS media. a) placement of potato meristem with $3.0 \mathrm{mg} \mathrm{L}^{-1} \mathrm{BAP}+0.2 \mathrm{mg} \mathrm{L}^{-1} \mathrm{GA}_{3}$, b) gradual development of initial calli from meristem at $10 \mathrm{DAI}, \mathrm{c})$ initiation of regenerating shoot from calli of meristem at 30DAI of Heera with $3.0 \mathrm{mg} \mathrm{L}^{-1} \mathrm{BAP}+0.2 \mathrm{mg} \mathrm{L}^{-1} \mathrm{GA}_{3}$, d) regenerating shoot from initiated calli of meristem at $50 \mathrm{DAI}$ of Heera 

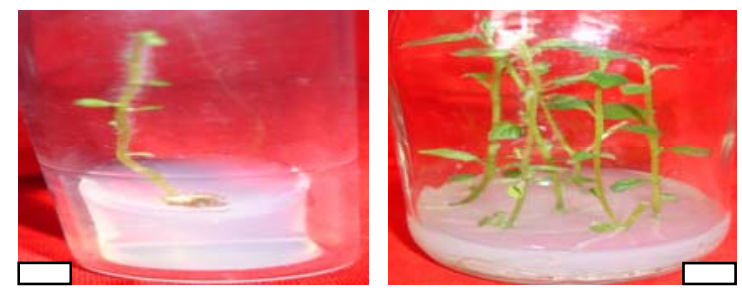

Figure 4. Different growth stages of virus free regenerating plantlets. a) regenerating plantlets from initiated calli of Diamant derived from meristem with $3.0 \mathrm{mg} \mathrm{L}^{-1} \mathrm{BAP}+0.2 \mathrm{mg} \mathrm{L}^{-1} \mathrm{GA}_{3}$ at 55 DAI, b) subcultured virus free plantlets of Diamant derived from meristem on MS media at 15 DAC.

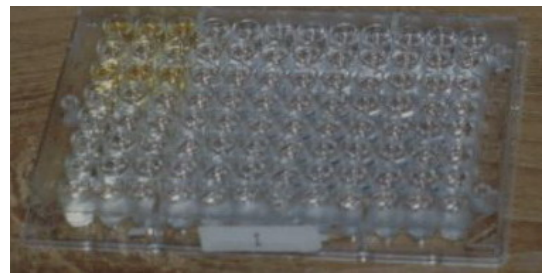

Figure 5. In ELISA test, no yellow colour development in micro titer wells indicating virus freeness of the sample plantlets derived from meristem culture.

Role of variety on virus elimination from potato through meristem culture Statistically significant difference was found among the varieties for percent survival of meristem and production of percent virus free plantlets derived from meristem of PVY infected potato (Fig. 2). For survival the best (25.85\%) response was found in Lalpakri, the next being in Heera and proved to be good respondent. The least (19.08\%) responsive was Diamant among the PVY infected plantlets. Khanom (1984) investigated that among the local varieties Lalpakri gave the highest (96.00) survival percentage followed by Lalsheel. The least $(53.37 \%)$ responsive being Jhaubilati, which supports the results of the present investigation, where Lalpakri was the best responsive in case of PVY elimination. The local varieties showed better performance in survival rate of meristem than the exotic cultivers. In the present investigation, Heera was found better than Diameant. However, as it appears, the higher survival percentage of meristem derived plantlets may not be a varietal character rather it depends on many other factors such as size of meristems, method of excision of meristem, degree of temperature and precautions followed during inoculation.

Percentage of PVY virus eliminated meristem derived from 90 days old plantlets of three potato varieties are shown in Fig. 2. The highest (33.27) percentage of PVY virus free plantlets was observed in Heera which was followed by Diamant and the least (31.97) was found in Lalpakri plantlets. The role of varieties in obtaining plantlets free from viruses was negligible, which ranged from 33.27 to $31.97 \%$ in the present investigation. Irrespective of varieties, size of the meristem 
was a factor for obtaining virus free plantlets. Bokx (1972) attached similar importance to the size of the meristem for virus elimination in potato.

\section{Combined effects of $\mathrm{BAP}$ and $\mathrm{GA}_{3}$ on virus elimination of potato through meristem culture}

Combined effects of BAP \& $\mathrm{GA}_{3}$ differed significantly in both the parameters studied (Table 1). Combination of $3.0 \mathrm{mg} \mathrm{L}^{-1} \mathrm{BAP}$ and $0.2 \mathrm{mg} \mathrm{L}^{-1} \mathrm{GA}_{3}$ showed the highest (46.11) survival followed by $4.5 \mathrm{mg} \mathrm{L}^{-1} \mathrm{BAP}+0.2 \mathrm{mg} \mathrm{L}^{-1} \mathrm{GA}_{3}$ and the lowest (6.52) survivality was observed when $1.5 \mathrm{mg} \mathrm{L}^{-1} \mathrm{BAP}+0.0 \mathrm{mg} \mathrm{L}^{-1} \mathrm{GA}_{3}$ was used. When the medium fortified only with $\mathrm{GA}_{3}$ didn't show any response. BAP + $\mathrm{GA}_{3}$ combination showed a good percentage of virus free plantlet production during meristem culture of potato which varied from 63.39 to $32.25 \%$. Combination of 3.0 $\mathrm{mg} \mathrm{L}^{-1} \mathrm{BAP}$ and $0.2 \mathrm{mg} \mathrm{L}^{-1} \mathrm{GA}_{3}$ showed the highest (63.39) percentage of virus free plantlet production followed by $4.5 \mathrm{mg} \mathrm{L}^{-1} \mathrm{BAP}+0.2 \mathrm{mg} \mathrm{L}^{-1} \mathrm{GA}_{3}$ and $1.5 \mathrm{mg} \mathrm{L}^{-1}$ $\mathrm{BAP}+0.2 \mathrm{mg} \mathrm{L}^{-1} \mathrm{GA}_{3}$, respectively and least (32.25) was in $1.5 \mathrm{mg} \mathrm{L}^{-1} \mathrm{BAP}$ and 0.0 $\mathrm{mg} \mathrm{L}^{-1} \mathrm{GA}_{3}$. Medium without BAP and $\mathrm{GA}_{3}$ and medium fortified with 0.2, 0.4 and $0.6 \mathrm{mg} \mathrm{L}^{-1} \mathrm{GA}_{3}$ showed no response (Table 1). It is concluded from these studies that BAP was responsible for growth and survival of the meristem explant as well as virus free plantlet production. $\mathrm{GA}_{3}$ alone cannot help to survive or promote the growth of meristem derived explant.

Table 1: Percentage of survival and virus elimination of meristem derived plantlets in different hormone combinations of potato followed by thermotherapy.

\begin{tabular}{|c|c|c|c|}
\hline \multicolumn{2}{|c|}{$\begin{array}{c}\text { BAP + GA } \\
\text { combination }\left(\mathrm{mg} \mathrm{L}^{-1}\right)\end{array}$} & \multirow{2}{*}{$\begin{array}{c}\text { Survival of meristem } \\
\text { derived plantlets } \\
\text { (\%) }\end{array}$} & \multirow{2}{*}{$\begin{array}{c}\text { Virus free plantlets derived } \\
\text { from meristems } \\
(\%)\end{array}$} \\
\hline BAP & $\mathbf{G A}_{3}$ & & \\
\hline \multirow{4}{*}{0.0} & 0.0 & - & - \\
\hline & 0.2 & - & - \\
\hline & 0.4 & - & - \\
\hline & 0.6 & - & - \\
\hline \multirow{4}{*}{1.5} & 0.0 & 6.521 & $32.25 \mathrm{k}$ \\
\hline & 0.2 & $39.71 \mathrm{c}$ & $50.50 \mathrm{c}$ \\
\hline & 0.4 & $30.93 \mathrm{f}$ & $44.00 \mathrm{f}$ \\
\hline & 0.6 & $29.13 \mathrm{~h}$ & $41.54 \mathrm{~g}$ \\
\hline \multirow{4}{*}{3.0} & 0.0 & $14.88 \mathrm{k}$ & $33.90 \mathrm{j}$ \\
\hline & 0.2 & $46.11 \mathrm{a}$ & 63.39 a \\
\hline & 0.4 & $36.69 \mathrm{~d}$ & $49.02 \mathrm{~d}$ \\
\hline & 0.6 & $32.34 \mathrm{e}$ & $47.08 \mathrm{e}$ \\
\hline \multirow{4}{*}{4.5} & 0.0 & $24.43 \mathrm{j}$ & $34.50 \mathrm{j}$ \\
\hline & 0.2 & $42.44 \mathrm{~b}$ & $52.63 \mathrm{~b}$ \\
\hline & 0.4 & $29.87 \mathrm{~g}$ & $37.48 \mathrm{~h}$ \\
\hline & 0.6 & $26.84 \mathrm{i}$ & $35.88 \mathrm{i}$ \\
\hline
\end{tabular}

The figures in a column with same letter(s) do not differ significantly. 
Combined effects of temperatures and varieties on virus elimination of potato through meristem culture

Interaction of temperatures and potato varieties showed significant differences for percentage of survival of meristem derived plantlets and percent virus free plantlets at 90 DAI (Table 2). Meristem of Lalpakri when thermotherapy with $27 \pm 1^{\circ} \mathrm{C}$ showed the highest (28.06) survival of shoot followed by Lalpakri with $30 \pm 1^{\circ} \mathrm{C}$, Heera with $27 \pm 1^{\circ} \mathrm{C}$, Lalpakri with $35 \pm 1^{\circ} \mathrm{C}$. Whereas, the least (17.52) success in survival percentage was attained in Diamant with $35 \pm 1^{\circ} \mathrm{C}$. Heera showed the highest (44.50) virus free plantlet production followed by Diamant, Lalpakri with $35 \pm 1^{\circ} \mathrm{C}$ and the least (14.46) in Lalpakri with $27 \pm 1^{\circ} \mathrm{C}$.

A wide variation on success of obtaining in vitro plantlet through meristem culture was observed at different treatments. Irrespective of heat treatment, more or less equal size meristem was excised in this investigation. The control $\left(27 \pm 1^{\mathrm{O}} \mathrm{C}\right)$ temperature showed better results than other temperatures $\left(30 \pm 1^{\circ} \mathrm{C}\right.$ and $35 \pm 1^{\circ} \mathrm{C}$, respectively). This result indicated that temperature has a marked effect on the success of meristem culture. The meristems were exposed to high temperature directly, might have had adverse effect on metabolic activities of the meristem. Of course, meristem size and other factors incorporated here would have effect on survival of meristem (Walkey, 1980), but these were assumed common to all treatments. Bjarnason (1986) and Bokx (1972) observed varietal differences on in vitro growth of meristem which supports the result of the present investigation.

Table 2: Interaction effects of different temperature treatment and varieties on percentage of survival and virus freeness of meristem derived plantlets during meristem culture of potato followed by thermotherapy

\begin{tabular}{cccc}
\hline $\begin{array}{c}\text { Interaction } \\
\begin{array}{c}\text { Different temperature } \\
\text { treatment }\end{array}\end{array}$ & $\begin{array}{c}\text { Potato } \\
\text { varieties }\end{array}$ & $\begin{array}{c}\text { Survival of meristem } \\
\text { derived plantlets } \\
\mathbf{( \% )}\end{array}$ & $\begin{array}{c}\text { Virus free plantlets } \\
\text { derived from meristem } \\
\mathbf{( \% )}\end{array}$ \\
\hline \multirow{2}{*}{$(27 \pm 1)^{\mathrm{O}} \mathrm{C}$} & Diamant & $21.00 \mathrm{f}$ & $15.24 \mathrm{f}$ \\
& Heera & $24.58 \mathrm{c}$ & $15.80 \mathrm{f}$ \\
& Lalpakri & $28.06 \mathrm{a}$ & $14.46 \mathrm{~g}$ \\
\hline \multirow{2}{*}{$(30 \pm 1)^{\mathrm{O}} \mathrm{C}$} & Diamant & $18.73 \mathrm{~h}$ & $38.89 \mathrm{e}$ \\
& Heera & $22.68 \mathrm{e}$ & $39.50 \mathrm{~d}$ \\
\multirow{2}{*}{$(35 \pm 1)^{\mathrm{O}} \mathrm{C}$} & Lalpakri & $25.96 \mathrm{~b}$ & $38.43 \mathrm{e}$ \\
& Diamant & $17.52 \mathrm{i}$ & $43.86 \mathrm{~b}$ \\
& Heera & $20.39 \mathrm{~g}$ & $44.50 \mathrm{a}$ \\
& Lalpakri & $23.51 \mathrm{~d}$ & $43.02 \mathrm{c}$ \\
\hline
\end{tabular}

The figures in a column with same same letter(s) do not differ significantly.

\section{REFERENCES}

BBS. 2007. Statistical Pocket Book of Bangladesh (April 2008). Bangladesh Bureau of Statistics. Bangladesh Secretariat, Dhaka- 1000. pp. 139 \& 209.

Beukema, H. P. and Vander Zaag, D. E. 1990. Introduction to Potato Production. Pudoc, Wageningen. pp. 13-24. 
Bjarnason, N.N. 1986. Elimination of viruses from infected plants using heat-treatment and meristem tip culturing. Bull., Pl. Res. Ins., Burnley.

Bokx, de. J.A. 1972. Viruses of potato and seed potato production. Gen. Agric. Publ. Doc., Wageningen. pp. 158-166.

Bryan, J. E. 1989. Breaking dormancy of potato tubers. CIP Res. Guide, Lima, Peru, 16:12.

El-Amin, S. M., Valkonen, J. P. T., Bremer, K. and Pehu, E. 1994. Elimination of Viruses and hypersensitivity to Potao Virus Y (PVY) in an important Sudanese Potato stock. American Journal of Potao Research, 71(4): 267-272.

Jones, M.G.K., Vasil (eds.), I.V. and Thorpe, T.A. 1994. In vitro culture of potato. Pl. Cell Tiss. Cult. pp 363-378.

Khanam, O. N. S. 1984. An attempt to produce virus free potato plant through tissue culture. M. Sc. Thesis submitted to the Dept. of Bot. Univ. of Dhaka. 115p.

Miller, S.S. and Lipschutz, L. 1984. Root and tuber crops (potato). In: Handbook of Plant Cell Culture (P.V. Ammivato, D.A. Dvans, W.R. Sharp and Y. Yamoda eds.). Macmillan Publ. Co., NY, pp. 291-326.Pennazio, S. and m. Mocchiati. 1976. Effects of naphthaleneacetic acid on potato meristem tip development. Potato Research, 19(3): 257-261.

Murashige, T. and Skoog, F. 1962. A revised medium for rapid growth and bioassays with tobacco tissue cultures. Physiol. Plant., 15: 473-497.

Omidi, M, Shahpiri, A. and Yada, R.Y. 2003. Callus induction and plant regeneration In vitro in potato. Potatoes - Healthy Food for Humanity: International Developments in Breeding, Production, Protection and Utilization. Proceedings of the XXVI International Horticultural Congress, Toronto, Canada, 11-17 August, 2002. ActaHorticulturae. 2003, No.619, 315-322.

Pennazio, S., Vecchiati, M. and Virgilio, A. De. 1979. Elimination of Potato Virus X by means of heat treatment combined with meristem tip culture. Rivista della Ortoflorofruitticoltura Italiana. 63(2): 103-113 [Cited from Pot. Abst., 5(5): 8, 1980].

Rashid, M. H., Akhter, S., Elias, M., Rasul, M. G. and Kabir, M. H. 1993. Seedling tubers for ware potato production: Influence of size and plant spacing. Asian Potato Journal, 3 : 14-17.

Siddique, M.A. and Hussain, M.M. 1988. Production of local potato varieties (in Bangla). Bangladesh-Netherlands Seed Mult. Proj., BADC, Dhaka. p. 20.

Stace-Smith, R. and Mellor, F.C. 1968. Eradication of Potato Virus X and S by Thermorheraphy and axillary bud culture., Phytopath., 58: 199-203.

Vander Zaag, D.E. 1987. Growing seed potatoes. In : DeBokx, A. E and Van der Want, J. P. H. (eds). Viruses of potatoes and seed potato production Second Edition. Pudoc, Wageningen.

Walkey, D.G.A. 1980. Production of virus-free plants by tissue culture. In: Tissue Culture Methods for Plant Pathologist(D.S. Ingram and J.P. helgeson eds.), Blackwell Sci. Publ. Co., Oxford. p. 272.

Zapata, C., Creighton Miller, J. Jr. and Smith, R. H. 1995. An in vitro procedure to eradicate potato viruses $\mathrm{X}, \mathrm{Y}$, and S from Russet Norkotah and two of its strains. In vitro cellular \& developmental biology. Plant, 31(3): 153-159.

Zhuk, I.P. 1978. Culture of apical meristem as a method of elimination of virus diseases of potato. Biologiya, 13(4): 512-516. 